\title{
Socio-economic Implications of Child Trafficking In Borno State, Nigeria.
}

\author{
${ }^{1}$ Egwu, Grace E., ${ }^{2}$ Ahmed, Funmilola, F. (Ph.D), \\ and ${ }^{3}$ Tukur, Mohammed D \\ ${ }^{I}$ Department of Sociology, University of Maiduguri, Borno State \\ ${ }^{2}$ Department of Economics, University of Maiduguri, Borno State \\ ${ }^{3}$ Department of Economics, University of Maiduguri, Borno State
}

\begin{abstract}
Globally, children of school age are bought, sold and transported away from their homes as commodities. Child trafficking is illegal and extremely harmful as trafficked children are exposed to diverse forms of abuse. The general objective of this study was to examine the socioeconomic implications of child trafficking in Borno State, Nigeria. Using purposive and simple random techniques, data for the study were obtained from 92 respondents representing the immigration, police officers, lawyers, road transport workers, journalists and civil servants who deal directly with child traffickers and trafficked children. Descriptive statistics were used to analyze the data. The data revealed that trafficked children were obtained from other states, their age range was between five and 10 years and mostly males. It was discovered that force/coercion, trickery and administration of oats were the commonest methods used in child trafficking. Forced labour, prostitution and child soldier were the major purposes for child trafficking while poverty, economic gains, ignorance and insufficient penalties against traffickers were factors enhancing child trafficking in the study area. The study recommended among others investment in human capital, massive public enlightenment campaigns, severe penalties and removal of constraints hindering prosecution of traffickers.
\end{abstract}

Keywords: Child trafficking, socioeconomic implications

\section{Introduction}

Child trafficking is a universal phenomenon. Child trafficking is the third largest criminal activity in the world after arms and drug trafficking (Tola, 2008). In the last decade, the phenomenon of child trafficking has considerably increased throughout the world and most especially in Nigeria. Every year, millions of individuals mostly children are misled by deceit or forced to submit to servitude. Trafficking of children links all countries and religions in a web of international crime. Every year, children are smuggled across borders and sold like commodities and others are trafficked within their home countries, usually from rural to urban areas.

Jacqueline (2006), described child trafficking as the recruitment, transfer, habouring or receipt of persons for the purpose of exploitation, using illicit means such as coercion, abduction and deception. The trafficking of children is one of the greatest violations of human rights in the world today. Children and their families are ensnared by the empty promises of the trafficking networks' promises of a better life, is an escape route from poverty and every year hundreds of thousands of children are smuggled across borders and sold as mere commodities. Their survival and development are threatened and their rights to education, health, grow up within a family, protection from exploitation and abuse, are denied (O'Nelill, 2000).

Child trafficking is a social ill which is sometimes attributed to the extreme poverty faced by some parents. These parents are misinformed by traffickers to believe that their standard of living will improve as well as their children (Ayua, 1999). Some parents sell off their children or give them to traffickers with the hope that the children will receive better education/training. Purposes of human trafficking are force labour, forced marriages and domestic servitude. Children are thus mostly trafficked for cheap labour exploitation. Others for instance from Asia, Africa, South America are sold out or forced into global sex trade as prostitutes and pornography. Children of school ages have fallen victim of human trafficking and are tied down as slaves in very deplorable conditions under masters/mistresses as a result of this inhuman activity. They have lost the love and care that they need as children from parents, and have fallen into an adult world untimely. Some have migrated to far-off unknown locations, into unfamiliar traditional fostering arrangements (Tola, 2008). In the report of Afonja (2001), some children left home due to hardship and deprivation, others fell prey to traffickers having run away from extended family members due to abuse. Such children will not agree that they are trafficked, hence the difficulty in applying the law.

Globally, children of school age are bought, sold and transported away from their homes as commodities. The trafficking of human being is a multibillion dollar business that appears to be growing. Child 
trafficking is illegal and is extremely harmful, as trafficked children are physically and sexually exploited and abused (ILO-IPEC, 2002). Obtaining accurate data on child trafficking is difficult because it is a hidden criminal activity. The invisible and clandestine nature of trafficking makes it difficult to know the number of child victims. However, the Federal Office of Statistics / International Labour Organization (FOS/ILO), National Child Labour Survey (2003), estimates 2000,000 - 800,000 women and children trafficked yearly, National Agency for Prohibition of Traffic In Persons (NAPTIP) / United Nations Children's Fund (UNICEF) assessment of child trafficking in Nigeria 2003 reported that about 54\% of repatriated victims of external trafficking in Nigeria are children with a female ratio of 7:3. Of this figure, $46 \%$ were engaged mainly in prostitution, $21 \%$ in domestic labour, $15 \%$ in forced labour and $8 \%$ in entertainment. According to UNICEF, (2006), at least 1.3 million children were trafficked for child labour, mostly but not exclusively in developing countries.

In Nigeria, the wife of the former Vice President, Mrs Titi Abubakar in 1999 spear headed a bill which became law in 2003, as the National Agency for the Prohibition of Traffic in Persons and other Related Matters (NAPTIP), to curb human trafficking and other related matters. In Nigeria, boys are mostly trafficked from south eastern states of Imo, Abia and Akwa Ibom to Gabon, Equitorial Guinea and Congo, while those from kwara go to Togo, Mali to work on plantations. Some are brought in from katsina State and Kano State to Borno for child labour and later trafficked to Chad, Niger and Cameroun en route Italy for so called "greener pasture" (NAPTIP, 2003). Despite governments, efforts to curb child trafficking, the problem still persists, most especially in states that share boundaries with other countries. It is noteworthy that Nigeria is a source, transit and destination country for child trafficking (Fitzgibbon, 2003).

Borno State is therefore not likely to be an exception to the problem of child trafficking. Moreover, being a state that share borders with three countries is also a route for trading and commercial activities with neighboring countries of Cameroon, Chad and Niger Republics. Therefore, as a trans-border state, Borno is likely to be a pivot-point for child trafficking activities. Children have been trafficked from Niger and Chad and brought to Borno as child beggars and child labourers. Also, the nature of Borno State as a trade route to the Middle East region has led to a beehive of commercial activities including commerce in children to serve as house helps and prostitutes (Atsev, 2000). Furthermore, Borno State is a famous center for Islamic learning. Trafficking exists between Katsina, Kano and Maiduguri due to the Almajirai system of education (Akinboyo, 2005). Children are brought in for learning but may end up being used as destitute to ferment trouble within the society. They are used as thugs to harass political opponents with little money from oppressive politicians. Most of these children have lost parental love and affection as normal children hence lack human sympathy and pathos. As opined by Zannah, (2006), in some circumstances, children end up working for many hours in exploitative conditions just to survive and/or used for rituals. However, the extent of these activities remains largely unknown and filling this gap is the concern of this research. Hence, the objectives of this study were to examine the socioeconomic characteristics of respondents; identify methods of child trafficking; examine the purpose for child trafficking; determine the factors responsible for child trafficking in the study area; and examine the consequences of child trafficking in the study area.

\section{The Study Area}

\section{Methodology}

The study was conducted in Borno State located in the North-eastern part of Nigeria. It lies between latitudes $12^{\circ} .00 \mathrm{~N}$ and $14^{\circ} .00 \mathrm{~N}$ and longitudes $10^{\circ} .00 \mathrm{E}$ and $14^{\circ} .00 \mathrm{E}$. Within the north-east, the State shares borders with Adamawa State to the south, Yobe State to the west, and Gombe State to the southwest. It also shares international borders with the Republic of Niger to the north, Chad to the north-east and Cameroon to the East which are major routes for child trafficking (Akinboyo, 2005). The state has an area of 75,540 km ${ }^{2}$ and 27 Local Government Areas spread over four major agro-ecological zones. The arid or sahel to the north, sudan Savannah in the centre and the northern and southern guinea Savanna to the south of the State. The provisional census figure gives the population of the state as 5.1 million people in 2012. (National Population Commission, $2006)^{1}$. Borno State is pluralistic in ethnic composition with the Kanuri being the dominant ethnic group. The vegetation is mainly of dry savannah type with variable rainfall. The rainfall lasts for 120 days in good years with annual rainfall ranging from $500 \mathrm{~mm}$ in the north to $1200 \mathrm{~mm}$ in the south. Rainy season is from June to September in the sahel and sudan Savannah and May to October in the Guinea Savannah. The agro-ecological zones reflect the types of crops grown and the major limiting factor is moisture in view of the rampant drought occurrences in the region (Adepejin, 2005). Agriculture is the main stay of the State's economy. The major crops cultivated in the State are millet, sorghum, maize, groundnut, wheat, cowpea, soybeans (which has become a major crop in southern Borno in recent years) and vegetables (onions, pepper, tomatoes, garden eggs and other leafy vegetables). The major livestock reared in the State are cattle, camel, sheep and goats. 


\section{Data Collection}

Both purposive and simple random sampling techniques were employed for this study. The purposive sampling was used to select the target population which constitutes immigration officers, police officers, legal practitioners, transporters, journalists and civil servants. Simple random sampling was used to select 100 respondents from the target population but only 92 were analyzed as others were discarded for inconsistency or incompleteness. For the purpose of the study, well structured questionnaires, oral interviews and documentary sources were used as research instruments. Descriptive statistics were employed to analyze the data.

\section{Data Presentation And Discussion of Findings}

This section focused on the presentation and analysis of data on Child Trafficking in Borno State, Nigeria.

Table 1: Gender Distribution of Respondents

\begin{tabular}{ccc}
\hline Gender & Frequency & Percentage of Total \\
\hline Male & 71 & 77 \\
Female & 21 & 23 \\
Total & $\mathbf{9 2}$ & $\mathbf{1 0 0}$ \\
\hline
\end{tabular}

Source: Field Survey, 2012

The gender distribution of the household heads in Table 1 shows that majority of respondents (71\%) were males and $21 \%$ were females. Most females in the study area were unwilling to either fill the questionnaire or participate in the oral interview. This is largely associated to the religious inclinations and they opined that the issue of child trafficking is mainly men affair.

Table 2: Age distribution of Respondents

\begin{tabular}{ccc}
\hline Age (years) & Frequency & Percentage of Total \\
\hline Below $\mathbf{2 5}$ & 0 & 0 \\
$\mathbf{2 6} \mathbf{- 3 0}$ & 17 & 18.5 \\
$\mathbf{3 1}-\mathbf{3 5}$ & 24 & 26.1 \\
$\mathbf{3 6}-\mathbf{4 0}$ & 28 & 30.4 \\
$\mathbf{4 1}$ and above & 23 & 25 \\
Total & $\mathbf{9 2}$ & $\mathbf{1 0 0}$ \\
\hline
\end{tabular}

Source: Field Survey, 2012

Results in Table 2 shows that about $26 \%$ and $30 \%$ of the sample population belonged to the age range between $31-40$ years old. It is noteworthy, however that all the respondents are adults. This implies that respondents are old enough to understand the subject matter.

Table 3: Educational Qualification of Respondents

\begin{tabular}{ccc}
\hline Educational Level & Frequency & Percentage of Total \\
\hline PRIMARY SCHOOL & 2 & 2.2 \\
SSCE/GCE & 12 & 13.1 \\
OND/HND & 34 & 36.9 \\
B.SC/B.A & 22 & 23.9 \\
HIGHER DEGREE & 15 & 16.3 \\
PROFESSIONALS & 7 & 7.6 \\
Total & $\mathbf{9 2}$ & $\mathbf{1 0 0}$ \\
\hline
\end{tabular}

Source: Field Survey, 2012

The educational qualification of the respondents indicates that about $37 \%$ of the respondents were OND/HND degree holders, about $24 \%$ were B.SC/BA degree holders. About $77 \%$ of the sample population had tertiary education. This implies that most respondents are literate and can understand the subject matter with its attendant implications. This group may also likely form the decision making body for eradication of child trafficking in the study area.

Table 4: Duration of Respondents' stay in Borno State

\begin{tabular}{ccc}
\hline Duration (years) & Frequency & Percentage of Total \\
\hline $\mathbf{1 ~ - 5}$ & 15 & 16.3 \\
$\mathbf{6 - 1 0}$ & 24 & 26.1 \\
$\mathbf{1 1} \mathbf{- 1 5}$ & 16 & 17.4 \\
$\mathbf{1 6 - 2 0}$ & 20 & 21.7 \\
$\mathbf{2 1}$ and above & 17 & 18.5 \\
Total & $\mathbf{9 2}$ & $\mathbf{1 0 0}$ \\
\hline
\end{tabular}

Source: Field Survey, 2012 
Table 4 shows that about $84 \%$ of the respondents have lived in the state for more than 6 years. This implies that respondents have lived in the state for a reasonable number of years to comment on the subject matter. Also, respondents' occupational inclinations predispose them to relevant information on child trafficking in the study area.

Table 5: Origin of Trafficked Children

\begin{tabular}{ccc}
\hline Origin & Frequency & Percentage of Total \\
\hline Villages around Borno & 20 & 21.7 \\
From Other States & 65 & 70.7 \\
Neighboring Countries & 7 & 7.6 \\
& $\mathbf{9 2}$ & $\mathbf{1 0 0}$ \\
\hline
\end{tabular}

\section{Source: Field Survey, 2012}

As presented in Table 5, respondents are of the opinion that about $71 \%$ of the trafficked children are from other states (especially the northern states). It was observed that only $7 \%$ were trafficked from neighboring countries. The origin of the children was adjudged from their language and religious inclinations. The result also corroborated the view of Ayabola (2005) who observed that children trafficking occur along the borders of Borno State as truck loads of children are brought into Maiduguri weekly at "Tashan Lorry" on the disguise of religious education pursuits. However, most children end up as domestic workers, shop and restaurants attendants, hawkers, sex workers and for rituals.

Table 6: Age of Trafficked Children

\begin{tabular}{ccc}
\hline Age (years) & Frequency & Percentage of Total \\
\hline $\mathbf{5 - 1 0}$ & 68 & 73.9 \\
$\mathbf{1 1}-\mathbf{1 5}$ & 18 & 19.6 \\
$\mathbf{1 6}-\mathbf{2 0}$ & 6 & 6.5 \\
Total & $\mathbf{9 2}$ & $\mathbf{1 0 0}$ \\
\hline
\end{tabular}

\section{Source: Field Survey, 2012}

Table 6 reveals that majority (about 74\%) of children trafficked are between ages

5 and 10 years and the least trafficked are between 16 and 20 years old. This implies that children between ages 5 and 10 years are vulnerable and can easily be deceived. Children in this age bracket are supposed to be in primary school but are denied the fundamental necessities of life at tender age. This also buttressed the report of Gozdiak, (2006) who opined that trafficked children form more than half of trafficked victims. It is indeed a breach of the child's fundamental right.

Table 7: Sexes of Children Mostly Trafficked

\begin{tabular}{ccc}
\hline Sex & Frequency & Percentage of Total \\
\hline Males & 58 & 63 \\
Females & 34 & 37 \\
Total & $\mathbf{9 2}$ & $\mathbf{1 0 0}$ \\
\hline
\end{tabular}

\section{Source: Field Survey, 2012}

Results in Table 7 shows that boys $(63 \%)$ are reportedly more often trafficked than girls. This can be attributed to the fact that they are more resilient and rugged and mostly used to do house chores, assemble machines and bicycles/motorcycles and recruited as child soldiers in recent times. Traffickers also earn money on girl child trafficking as they are used as domestic helps, prostitutes, aids for begging and may likely be forced into marriages.

Table 8: Methods Employed in Child Trafficking.

\begin{tabular}{ccc}
\hline Methods & Frequency* & Percentage of Total \\
\hline Force/Coercion & 38 & 29 \\
Trickery & 47 & 35.9 \\
Administration of Oath & 25 & 19.1 \\
All the above & 21 & 16 \\
& $\mathbf{1 3 1}$ & $\mathbf{1 0 0}$ \\
\hline
\end{tabular}

\section{*Multiple Responses existed}

\section{Source: Field Survey, 2012}

Respondents observed that the most prevalent strategy employed in child trafficking is trickery which represents about $36 \%$ of the sample population. Also, force and coercion is widely practiced as mothers are forced to release their children as religion demands for training and children are forced to leave home due to mainly poverty but under the disguise of religion. Administration of oath also accounts for about $19 \%$. This makes child trafficking secretive as defrauders are likely to face death penalty. This implies that basically, child 
trafficking thrives on fraud and deception as traffickers promise the children and their parents or relations education and better life in future for the children in the urban/foreign lands. Zannah, (2006) observed that most trafficked people are from the villages and are told wonderful stories of life in urban centers and that children are easily gullible and can fall prey to deceit hence the statistics for trickery ranks highest.

Table 9: Purpose of Child Trafficking

\begin{tabular}{ccc}
\hline Purposes & Frequency & Percentage of Total \\
\hline Forced Labour & 37 & 40.2 \\
Prostitution & 24 & 26.1 \\
Pornography & 8 & 8.7 \\
Child soldier & 17 & 18.5 \\
All of the above & 6 & 6.5 \\
Total & $\mathbf{9 2}$ & $\mathbf{1 0 0}$ \\
\hline
\end{tabular}

Source: Field Survey, 2012

The purposes for child labour in the study area are enumerated in Table 9. The study revealed that children were trafficked mostly (about 40\%) for forced labour in the form of domestic helps, restaurants attendants, trade and begging. Prostitution purposes (about 26\%) also ranks high in the study area followed by recruitment as child soldier (about 19\%) and pornographic use (about 9\%). The result implies that trafficked children are exploited mainly for financial remuneration by their traffickers. The insecurity situation in the north east region of Nigeria has also fueled the use of children soldiers on the premise of religion and/or merger financial inducements. This result also corroborates the opinion of Tola, (2008) that trafficked children are exploited and dehumanized.

Table 10: Factors Enhancing Child Trafficking

\begin{tabular}{ccc}
\hline Factors & Frequency* & Percentage of Total \\
\hline Poverty & 48 & 40.3 \\
Economic & 34 & 28.6 \\
Ignorance & 17 & 14.3 \\
Insufficient Penalties & 13 & 10.9 \\
All of the above & 7 & 5.9 \\
Total & $\mathbf{1 0 9}$ & $\mathbf{1 0 0}$ \\
\hline
\end{tabular}

*Multiple Responses existed

Source: Field Survey, 2012

Table 10 reveals the factors enhancing child trafficking in the study area. Poverty (40.3\%) ranks highest on the list of factors enhancing child trafficking followed by economic (28.6\%). Other factors include ignorance $(14.3 \%)$ and insufficient penalty for offenders. Poverty naturally heightens children vulnerability to traffickers and also the most obvious way material poverty can lead to exploitation and abuse. This result also support the assertions of Martin, (2006) who observed that those who attempt to sell children into slavery or sexual exploitation do not seek their prey in comfortable suburbs; but in the poorest shanty towns or the most obscured rural areas and with promises of employment opportunities abroad, families in extreme poverty may send their children away to work. Child trafficking can be seen as the worst form of child labour. Akinboyo, (2005), attributed the high rate of child labour in Nigeria to poverty, worsened by chronic economic depression, debt burden and unfavourable socio-economic policies all of which affect the children more than any other group in the country. As a result of high level of poverty, the poor families in Nigeria are usually in dire need of money, which their children are exploited to provide.

The result also corroborates the view of Mku, (2002) who opined that after guns and drugs, human trafficking is the most lucrative trade in the world as resalable commodities. The trafficker, the trafficked and /or his/her parents/guardians are driven or motivated by economic gains. While the trafficker is in business to gain through exploitation and sale of the children as commodities, the victims are looking forward to a better life, income, education and so on. Trafficking indeed creates a cycle of destruction motivated by economic gains.

The United Nations Charter in Article 27 on a child parenting clearly states the recognition of the rights of every child to a standard of living adequate for a child's physical, mental, spiritual, moral and social development, within the family's financial ability, particularly the provision of nutrition, clothing and education or other skills. This obviously negates trafficking. Parents and/or guardians are either ignorant of the right of the child and/or whether the ideals of the conventions are opposed to the traditional concepts of children upbringing. Mku, (2002) also asserted that lack of respect for human rights leave the children vulnerable.

Respondents also observed that traffickers face low risk of arrest, persecution or other negative consequences. Traffickers have often exploited the lack of rule of law, the non-implementation of existing antislavery laws and corruption of judicial systems. These institutional lapses often allow perpetrators to go 
unpunished thereby fueling child trafficking on a large scale. Furthermore, cases against traffickers regularly fall apart due to lack of protection for witnesses and family involvement in sending a child away.

Furthermore, respondents observed that child trafficking has emotional, physical and psychological impact with serious implications. Trafficked children are reduced to mere commodities, dehumanized, abused, denied freedom and healthy living. They are separated from parents and loved ones and as such lack love and parental care. Trafficked children are full of shame, guilt, low esteem, frequently stigmatized and feel betrayed. Their experiences lead to nightmares, sleeplessness, ill-health, feeling of hopelessness and depression. In addition, the hope of having a good and secured future is shattered. Child trafficking is indeed a social menace.

\section{Conclusion And Recommendation}

The study focused on the socioeconomic analysis of child trafficking in Borno State. Child trafficking flourishes in the study area due to its nearness to the neighboring countries of Chad, Cameroun and Niger Republics coupled with the porous nature of the borders. Trafficked children are mostly forced, coerced or tricked by the traffickers mostly with the consent of their parents who are ignorant of what awaits their children at their destination. Major factors fueling child trafficking include among others poverty and economic gain by both trafficker and the trafficked persons and their parents. It is obvious that it is only the children of the poor and down trodden that are trafficked. Based on the findings of this study, the following recommendations are made:

This study showed that poverty level of households is an important factor that enhances child trafficking in the study area. It is observed that poverty reduction in the long run is not likely to achieve more success without major investment in human capital. The levels of income that can be earned depend critically on the level of education therefore efforts towards revitalization or establishment of community vocational centers for the youth, women and men to provide an opportunity for skills acquisition which will empower them for gainful employment and sustainable living are encouraged. Also, poverty alleviation programmes be implemented, more attention should be geared towards monitoring and sustenance of such strategies.

Relevant government agencies especially the media and the non-governmental organizations should embark on massive public enlightenment campaigns to educate the public on the cause and consequences of child trafficking.

Religious and opinion leaders should also be involved in the fight against child trafficking. These leaders are able to enforce laws and influence families positively against traditional practices that encourage child trafficking. Places of worship should also be used to preach against child trafficking.

The lack of serious punitive penalties against child trafficking has been a major reason the business thrives. Therefore, government through legislation should put in place stiff and severe penalties for offenders and all legal constraints militating against prosecution of child traffickers should be checked.

[1]. Adepejin, A. (2005). "Review of Research and Data on Human Trafficking in Sub-Saharan Africa" International Migration. 3(82): $2-5$

[2]. Akinboyo, G. (2005). Child Trafficking for Exploitative Child Labour: The Nigerian Experience. A paper presented at the SubRegional Workshop on Trafficking in Child Domestic Works Cotonou, Benin.

[3]. Atsev, C. (2000). "An overview of Child Trafficking in Borno State". Situation Analysis of Head of Administration and Anti Human Trafficking State CID, Maiduguri.

[4]. Ayua, I. A. (1999). The Rights of Children in Nigeria. Nigerian Institute of Advanced Legal Studies Lagos, Nigeria.

[5]. Fitzgibbon, K. (2003). "Modern Day Slavery: The Scope of Trafficking in Persons in Africa" African Security Review 1(12): 6

[6]. ILO - IPEC (2002). "The Economics of Child Trafficking" The Economist 2(3): 5.

[7]. Jacqueline, B. and Zard, F. (2006). "Smuggled or Trafficked" in Migration Review 7(6): 2-8.

[8]. Kara, S. (2009). "Sex Trafficking: Inside the Business of Modern Slavery" Columbus University Press.

[9]. Martin, R. (2006). Foundation Campaigns to End Child Trafficking. www.rickymartinfoundation.org

[10]. Mku, M.O. (2002). Trafficking in Human Beings especially Women and Children. Federal Ministry of Information Abuja.

[11]. NAPTIP (2003). NAPTIP handbook. Official Gazette 90(89):3.

[12]. NPC (2006). National Population Census.

[13]. O'Nelill, R. A. (2000). International Trafficking in Children to the United States: A Contemporary Manifestation of Slavery and Organized Crime. Centre for the study for Intelligence, Washington D. C.

[14]. Tola, A. O. (2008). Child Trafficking in Nigeria: Causes, Effects and Remedies. Ego Booster Books, Ogun State, Nigeria.

[15]. UNICEF (2006). The State of the World's Children: Exclude and Invisible. UNICEF Child Protection Division, New York.

[16]. Zannah, G. (2006). Overview of Human Trafficking and Child Labour: Focus on Borno State. A Paper Presented at A Two Day Sensitization Workshop for Stakeholders, Maiduguri. 